\title{
The Social and Political Dimensions of the Ebola Response: Global Inequality, Climate Change, and Infectious Disease
}

\author{
Harris Ali, Barlu Dumbuya, Michaela Hynie, Pablo Idahosa, Roger \\ Keil and Patricia Perkins
}

\begin{abstract}
The 2014 Ebola crisis has highlighted public-health vulnerabilities in Liberia, Sierra Leone, and Guinea - countries ravaged by extreme poverty, deforestation and mining-related disruption of livelihoods and ecosystems, and bloody civil wars in the cases of Liberia and Sierra Leone. Ebola's emergence and impact are grounded in the legacy of colonialism and its creation of enduring inequalities within African nations and globally, via neoliberalism and the Washington Consensus. Recent experiences with new and emerging diseases such as SARS and various strains of HN influenzas have demonstrated the effectiveness of a coordinated local and global public health and education-oriented response to contain epidemics. To what extent is international assistance to fight Ebola strengthening local public health and medical capacity in a sustainable way, so that other emerging disease threats, which are accelerating with climate change, may be met successfully? This chapter considers the wide-ranging socio-political, medical, legal and environmental factors that have contributed to the rapid spread of Ebola, with particular emphasis on the politics of the global and public health response and the role of gender, social inequality, colonialism and racism as they relate to the mobilization and establishment of the public health infrastructure required to combat Ebola and other emerging diseases in times of climate change.
\end{abstract}

H. Ali $・$ B. Dumbuya $・$ M. Hynie $・$ P. Idahosa $・$ R. Keil $・$ P. Perkins (corresponding author)

York University, Toronto, Ontario, Canada

e-mail: esperk@yorku.ca

H. Ali

e-mail: hali@yorku.ca

B. Dumbuya

e-mail: bdumbuya@yorku.ca

M. Hynie

e-mail: mhynie@yorku.ca

P. Idahosa

e-mail: pidahosa@yorku.ca

R. Keil

e-mail: rkeil@yorku.ca 


\author{
P. Perkins \\ e-mail: esperk@yorku.ca \\ H. Ali $\cdot$ P. Perkins $\cdot$ R. Keil \\ Faculty of Environmental Studies, York University, Toronto, Canada \\ B. Dumbuya \\ Disaster and Emergency Management Program, York University, Toronto, Canada
}

M. Hynie

York Institute for Health Research and Department of Psychology, York University, Toronto, Canada

P. Idahosa

Department of Political Science, York University, Toronto, Canada

\title{
Keywords
}

Ebola, Climate change, Health infrastructure, Community-based disease prevention, Global health initiatives, Urbanization, Stigmatization

\section{Introduction: Learning from Ebola}

The Ebola crisis of 2014-15 holds a number of lessons regarding global preparedness to meet the challenges posed by emerging diseases in times of climate change. These lessons relate to the causes and origins of the Ebola spread, the initial responses to the epidemic at the local level, international responses and their long-term effects, and global disparities in health access.

This chapter brings together a range of facts and commentary about the Ebola epidemic, focusing on the role of climate change in exacerbating socio-economic vulnerabilities, and extending the discussion and analysis to future/emerging diseases and their relation to global climate change.

By combining discourse analysis and sources of public information about the Ebola crises such as newspapers and online sources with statistics and academic analyses of local health systems, global institutions, climate change-induced weather patterns, social institutions, public opinion, economic trends, investment and urbanization, we present an interdisciplinary contextual analysis of emergent pressures on local health systems in times of climate change, with global implications. While direct causality among factors is nearly impossible to "prove" in complex circumstances such as this, systems researchers rely on such triangulation and multiple evidence-based methodologies to track trends and make sense of emergent linked phenomena (Klenk and Meehan 2015; Poteete et al. 2010; Roe 1998; Moran-Ellis et al. 2006). The literature on hazards and disasters distinguishes between the former as being a precondition (in the form of a hazardous agent or circumstance) to a disaster. A hazard is therefore a disaster waiting to happen. Hazardous conditions set the stage for a disaster to occur. In the case of Ebola, the hazardous agent is the virus itself. The virus itself does not in itself "cause" the outbreak, just as a hazard in itself does not "cause" the disaster. Rather, the social, political, cultural, economic and biophysical conditions and factors we write about in this chapter all contributed to enabling the disease to spread. Here the 
enablement of disease spread also, notably, extends to the outbreak response, including how these numerous factors hindered the outbreak response.

The following section discusses the Ebola epidemic's roots in globalization, international trade pressures, financial flows, Bretton Woods institutions, incapacity and created weakness in African health-care systems, and the prospects for addressing these inequities as climate change worsens. Section III gives more detail on how mining, transportation networks, urbanization, and the scale of environmental-economic transformation both in Africa and worldwide lead to the conditions in which new diseases emerge and spread. In Section IV, photos and statistics demonstrate the relationship between climate change, poverty, poor nutrition, eroding infrastructure, and Ebola transmission rates. Section $\mathrm{V}$ discusses the role of stigmatization in the political and global aid response to Ebola. Section VI examines the long-term impact of global health assistance on sustainable community-based health services. The Conclusion builds on this background to consider Ebola's lessons in relation to future and emergent health risks in times of climate change.

\section{Ebola, Globalization, and Neoliberal Retrenchment}

Ebola's emergence is grounded in the legacy of colonialism and its contribution to enduring inequalities within African nations and globally. The contemporary expression of this history is seen in the "Washington Consensus," the international aid industry and the underfunding and decentralization of service delivery, through privatization, reduced public expenditures, and lack of access to health care for the most vulnerable. Developmentalism still informs and has implications for the effectiveness of current public health responses. The racist discourse of the diseased, incapable African, requiring outsiders to swoop in to save the day, can only be superseded through sincere and authentic participatory approaches - real collaboration between global institutions such as the World Health Organization (WHO) and local public health and government officials.

The whole world bears the responsibility for the Ebola crisis. As noted by the People's Health Movement, "The epidemic, in all probability, will run its course and die down after leaving a trail of death and destruction (not) because we as a global community would have done very much right, but because of the nature of the virus itself. The moot question is, will we have learnt anything? Or will it be back to business as usual?" (PHM 2014:7). Market demand from consumers in Global North fuels the resource exploitation that produces the conditions in which the Ebola epidemic emerged, and other diseases are sure to follow. Ebola has its origin in "the unchecked exploitation of natural resources by international timber and mining companies," as The Observer (2014) noted in early October 2014 based on a WHO report on the disease.

As long as Ebola erupted sporadically in small villages along the global resource economies' path, as it did beginning in the 1970s, the outbreaks flared up and went away as quickly as the global corporations leave their tailings ponds behind. The situation is different now. The virus found its way along the human food chain towards the exploding centres of a rapidly urbanizing Africa. It reached large cities with their huge inequities, overcrowding, and underdeveloped sanitation and public health systems, and only extreme measures fuelled by moral panic have thus far (and perhaps temporarily) prevented its global spread in the same way SARS expanded across the globe in 2003. The unspoken divisions in how these measures play out reveal deep injustices at the global level. 
For example, in the early days of the Ebola crisis, some criticized the unavailability of vaccines to help the sick, despite the fact that several vaccines had been in development for many years in the Global North (Stanford 2014). It was also pointed out that a large pool of exposed but disease-resistant people, such as those now living in Ebolaravaged areas of West Africa, would facilitate the development of a serum-based vaccine. Even if a vaccine is developed and tested, will it ever be widely available and accessible to all those who need it, in Africa and globally? Will this become yet another source of profits for Big Pharma? As has often been noted, there are "tensions inherent in the socioeconomic construct that is today's pharmaceutical industry [which on one hand seeks to protect] the health of the public, but on the other it seeks to maximize profit" (Cohen, Illingworth, and Schuklenk 2006:2). There may, then, be an understandable concern that seeking a cure or antidote for Ebola might become either an opportunity for the pharmaceutical industry to use Africa as a laboratory (see Chippaux 2004), or as another source of profits for the pharmaceutical industry, rather than promoting the enhancement of well-being. Or, as David Healy has said more dramatically, "an incentive to chase blockbuster profits-doing so regardless of patient welfare" (Healy 2011:55).

The WHO, hit hard by UN retrenchment related to the 2008 global financial downturn, cut its budget and downscaled its activities rather than insisting on adequate support and new funding approaches, which left the WHO woefully unprepared to help Guinea, Liberia and Sierra Leone mount a speedy and effective Ebola response in early 2014 (PHM 2014; Lee 2009; Harman 2009; Kay and Williams 2009). This put organizations like Medecins san Frontières (MSF), missionaries, and Cuban doctors in the position of heroic first responders in very difficult circumstances.

Points out Ibrahim Abdullah, who teaches at the University of Sierra Leone (the oldest university in West Africa) in Freetown, the epicenter of the epidemic, "This is the neo-liberal scourge: if you privatize health care in the context of mass poverty, you get the Ebola epidemic. If, however, you put people at the centre of development by modernizing health and education, you can prevent Ebola. Ebola is about governance and modernity" (personal communication 2014). This crisis is neoliberal precisely because each of the three hardest-hit countries (Liberia, Sierra Leone and Guinea), in addition to suffering civil wars and large-scale human displacement over the past decade, were also encouraged to privatize health care and introduce-fee-for-service systems that crumbled amidst poverty - a recipe for the Ebola disaster (PHM 2014). This impoverishment has also opened up the same countries for land-grabs, mining exploitation, rapacious Foreign Direct Investment, agro-forestry, habitat destruction, and human displacement which destroys social resilience, endangers public health, and makes quarantine and disease-control systems nearly impossible to manage.

The only way to combat these trends is for African states to be encouraged and supported in the harder part of development: building health care and education systems that are public and sustainable. The Ebola crisis reveals, thus, both shorter term and longer term issues of development, which represent the deeper crisis affecting not only the three main Ebola-affected countries but global distribution in general. 


\section{Ebola's Roots in Extended Urbanization}

The West Africa of the 2014 Ebola epidemic is one of the fastest urbanizing regions on the planet (Diallo and Dilorenzo 2014; Salaam-Blyther 2014). Perhaps the most dynamic social process in Africa is its rapid urbanization (including peri- and suburbanization). The ravaging of the countryside by resource companies and the expansion of the urban fabric into regional hinterlands demonstrate the interface between humans and infectious disease.

This is, of course, not just an African story. A planetary process of urbanization is underway across vast networks of infrastructure lines, resource supply chains and human travel (Brenner 2014). As much of this urbanization leads to massive peripheral settlement in existing and new urban centres, often in contiguity with previously mostly undisturbed natural landscapes, we can speak of "suburban constellations" at the heart of the process (Keil 2013; Bloch 2015; Mabin 2013, Leahy 2011). A new landscape of risk emerges (Bloch et al. 2013). In mining towns, sometimes physically remote and isolated but connected through global metabolisms and labour markets, we can speak of a "feral" form of suburbanization that confronts human and non-human nature in direct encounter (Shields 2012). By 2030, it is expected that urbanized land on the planet will cover 1.2 million square kilometres which is twice as much as in 2000. This massive urbanization is unequally distributed across the globe, with China and Africa absorbing the lion's share of global urbanization during the next generation. We can expect significant consequences for climate change, biodiversity, etc. (Seto et al. 2012; Oxfam 2008). In this context, Ebola, once thought of as being an isolated problem in remote rural areas, has become an urban disease affecting cities and their peripheries, where its spread tends to be rapid and seemingly random due to massive human interaction and often dense and unhygienic living conditions.

In the past, disease outbreaks were associated with squalid and unhygienic urban conditions and the immobility of affected communities (Keil 2014). The new bundled problematique of urbanization, density, and migration has often been the source of huge moral panic (Wald 2008:114-156). Emerging forms of urbanization lack the infrastructure necessary to support communities in a health emergency. Places like Kroo Bay in Freetown, described by a journalist as "a labyrinth of shacks and muddy pathways perched at the edge of a large rubbish dump stretching out into the Atlantic Ocean" caused concern amongst health care professionals. One was quoted as saying that "These places are always prone to outbreaks" (Trenchard 2014 n.p.). But now the attention is on the (transnational) network of extended urbanization as "the virus is travelling effortlessly across borders by plane, car and foot, shifting from forests to cities and springing up in clusters far from any previously known infections. Border closures, flight bans and mass quarantines have been ineffective" (Diallo and Dilorenzo 2014 n.p.; see also Salaam-Blyther 2014; Keil 2011).

Standard textbooks on globalization and health tend to overlook the urban dimension and lean towards seeing urban political pathologies in the framework of the nation state system (Cockerham and Cockerham 2010; Price-Smith 2009). With the SARS crisis of 2003, the world was made aware of the importance of cities in the governance of global health crises (Ali and Keil 2008). But this also meant moving from public health governance in and by cities to global public health governance in urban society - a different challenge altogether. The Ebola crisis points further in this direction: public health institutions and procedures in cities are absolutely critical (and they often failed in the cases of SARS as well as Ebola). The time has come for a systemic and 
networked view of governance (and not just health governance) across the global urban expanse, the entire field of extended urbanization.

Global institutions, in their imperfection, have begun to act. Urban public health systems could be a prime target of international aid to stave off the Ebola threat while creating the conditions for future epidemic prevention. The WHO made a courageous step in 2008 to strengthen the roles of cities in improving public health and in the fight against Emerging Infectious Diseases (WHO 2009). While Ebola proved to be resistant to many conventional containment measures the strengthening of urban public health institutions in the overall architecture of global health governance and responses is certainly a path that must be pursued in future outbreaks of this and other infectious diseases as cities grow faster and in different patterns than in the past.

\section{Health Infrastructure, Climate Change, and Ebola's Spread}

The impoverished public health sector and desperate state of critical infrastructure in Guinea, Liberia, Mali and Sierra Leone - barely functioning hospitals, inaccessible and inadequate care with few medical staff, intermittent electricity, underdeveloped transportation networks and non-existent communication networks - are markers of the extent to which the Ebola outbreak was able to spread and impact the region (WHO 2012; Oladele et al. 2012). Lack of surveillance and monitoring - laboratory facilities delayed early Ebola diagnoses until March 2014. The region's history, beset by political and social unrest and internal strife, adds to the complexity. Both Liberia and Sierra Leone experienced over a decade long civil conflict that decimated their already weak public health infrastructure. Health care expenditure in these countries are heavily dependent on foreign aid, tied to commitments that often prohibit investments in public infrastructure (UNDP 2011) (Table 1). Furthermore, countries with a health care workforce below WHO's recommended critical threshold of 23 professionals (physicians, nurses and midwives) per 10,000 people have a lower resilience for diseases and epidemics (Afri-Dev.Info 2014; WHO 2014a) (Table 1).

Table 1 Health Statistics for Ebola-Affected Countries. Source: Afri-Dev.Info (2014), Dumont and Zurn (2007)

\begin{tabular}{|l|l|l|l|l|l|}
\hline & Guinea & Liberia & $\begin{array}{l}\text { Sierra } \\
\text { Leone }\end{array}$ & Mali & Nigeria \\
\hline Health Expenditure as a \% of GDP (2012) & 6.3 & 19.5 & 18.8 & 5.8 & 503 \\
\hline Life Expectancy (years) & 58 & 62 & 46 & 57 & 58 \\
\hline Population (thousands) & 11,451 & 4,190 & 5,598 & 14,854 & 168,834 \\
\hline Doctors & 940 & 51 & 136 & 1,291 & 58,363 \\
\hline Nurses \& Midwives & 4,408 & 978 & 1,017 & 6,715 & 224,943 \\
\hline Doctors, Nurses \& Midwives per 10,000 people & 1 & 3 & 2 & 3 & 20 \\
\hline Doctors working abroad & 99 & 122 & 236 & 160 & 4,611 \\
\hline Nurses Working abroad & 94 & 1,240 & 2,057 & 227 & 13,398 \\
\hline
\end{tabular}

It is no surprise that the Ebola response was weak and characterized by what MSF (2014) cites as huge gaps "in medical care, training of health staff, infection control, contact tracing, epidemiological surveillance, alert and referral systems, community mobilization and education" - important components of a comprehensive Ebola preparedness and response plan as outlined by the WHO. Mistrust, miscommunication, and 
The Social and Political Dimensions of the Ebola Response...

rumours fuelled community resistance and avoidance that interfered with public health measures in the region (Fofana 2014).

Unlike Nigeria and Mali, Sierra Leone, Liberia and Guinea's outbreak started in rural areas with porous geopolitical borders, plus woefully inadequate and inaccessible public health care, forcing people to seek alternative affordable and accessible traditional medicine (WHO 2015). Nigeria and Mali had successful outcomes for several reasons. First, as the epidemic was in its fourth month, they had enough time to draw Ebola preparedness and response plans. Second, both countries repurposed existing infrastructure for Ebola: Nigeria used its polio facility as an Ebola Response Centre and Mali equipped an existing laboratory for Ebola testing (WHO 2014b; WHO 2015). Third, the index case arrived in urban cities, where medical care was available (Nigeria's by air to Lagos City and Mali's via road to Bamako), allowing for quick diagnosis and activation of monitoring and contact tracing.

The region's colonial history depicts an exploitative and extractive relationship with the Global North since the 1800s, plus a history of disease importation to the region and is the backdrop that sheds light on the level of mistrust for national and international agencies that partly shaped public response to the Ebola outbreak. For example, in August 1918, the Spanish influenza arrived on the shores of Sierra Leone aboard a British naval vessel (Rashid 2011; Olaniyan 2004). Rural areas - the disease epicenter - are underserved. Post independence, national governments perpetuate this exploitative legacy. In Sierra Leone, rural agriculture and minerals account for a high percentage of national GDP, yet rural areas have not had proportional investment in basic infrastructure like health, water and sanitation and transportation networks (BTI 2012).

It is increasingly evident that climate change is adversely affecting human health. The health burden of climate change also includes the emergence and increased incidence of infectious and water borne diseases. The current Ebola outbreak was a chance encounter between a 2-year old child and a fruit bat, the reservoir for the virus (Baize et al. 2014; Saez et al. 2015; WHO 2015). Some studies cite climate variability as the cause for fruit bats to migrate long distances and reside near cities and towns (Frumkin et al. 2008; Pinzon et al. 2004). An Action Aid (2006) study on the increasing flood frequency in six African cities reports that "climate change is altering rainfall patterns and tending to increase storm frequency and intensity". In Sierra Leone, recent extreme weather observed include heavy rains that cause flash floods, mass land movement, injuries and fatalities, and infrastructure damage (Figure 1,2 and 3). Heavy rains precipitated the 2012 cholera epidemic that started in Guinea (7,350 cases and 133 fatalities) and eventually spread to Sierra Leone (23,124 cases and 299 fatalities) (WHO 2012). 


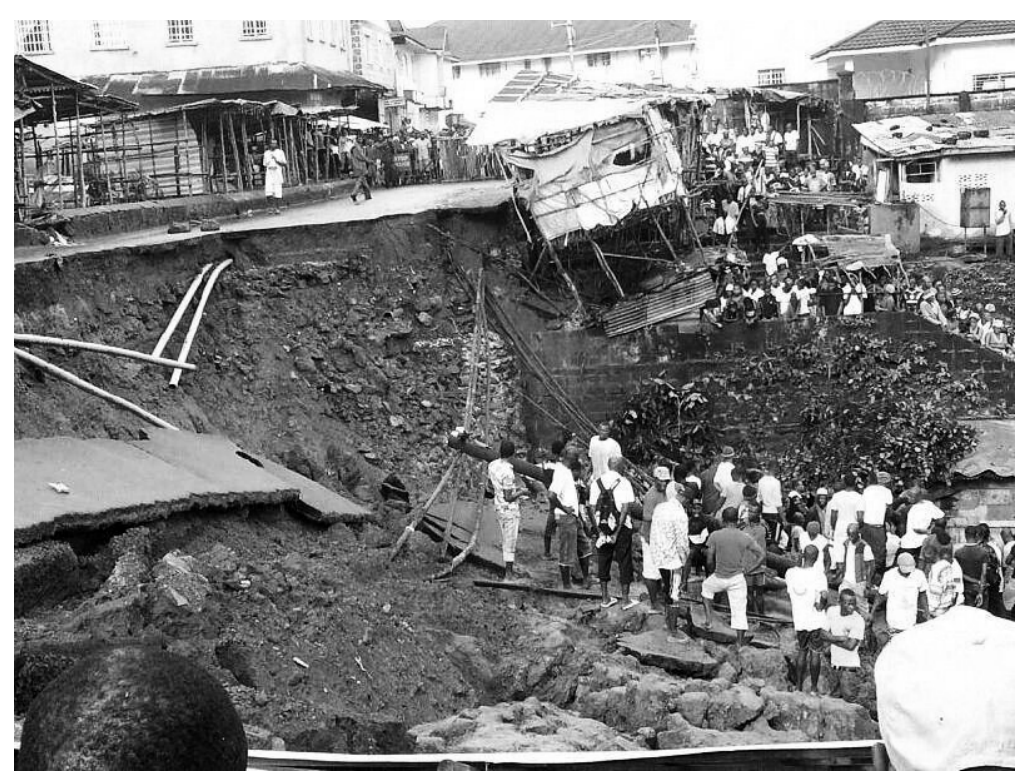

Fig. 1 Sierra Leone's King Jimmy bridge collapsed after torrential rains in August, 2013, killing 6 people.

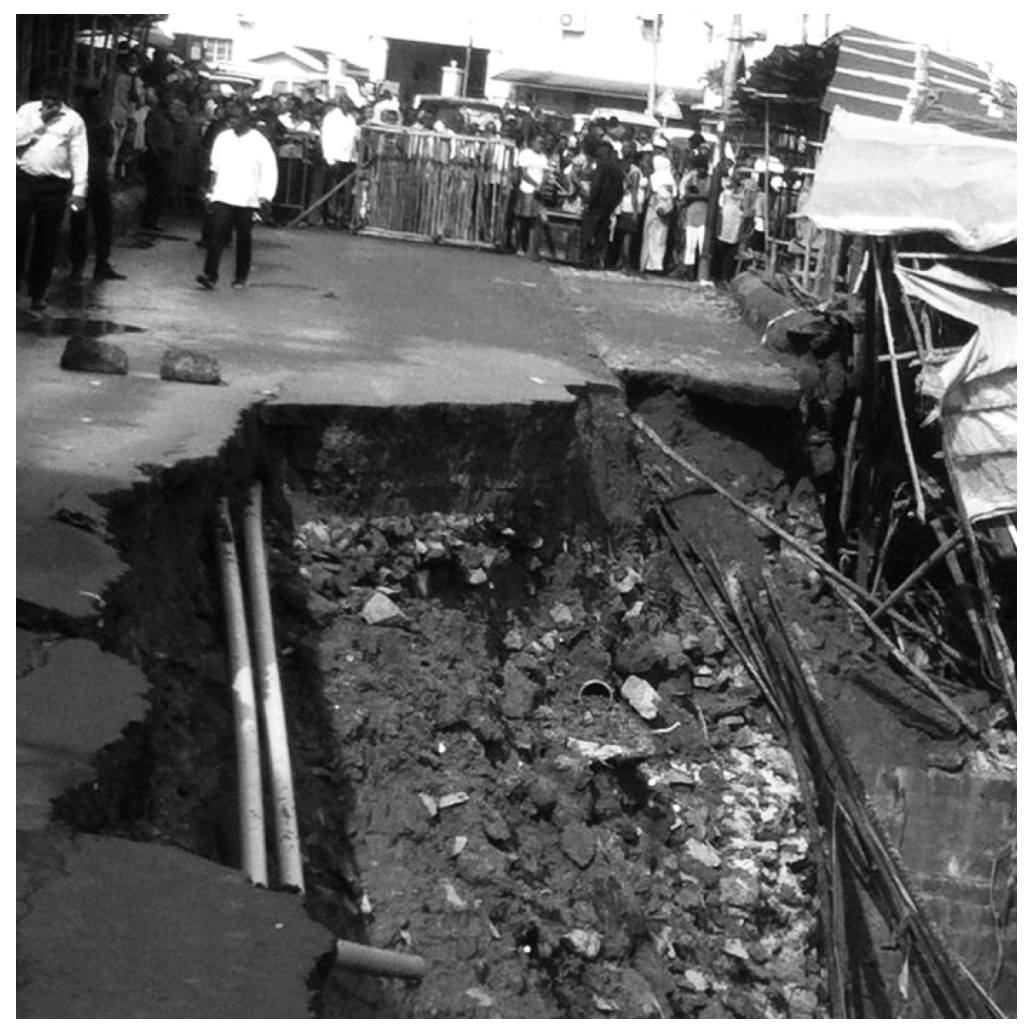

Fig. 2 Sierra Leone's collapsed King Jimmy bridge along Wallace Johnson Street in Freetown, August 2013. 


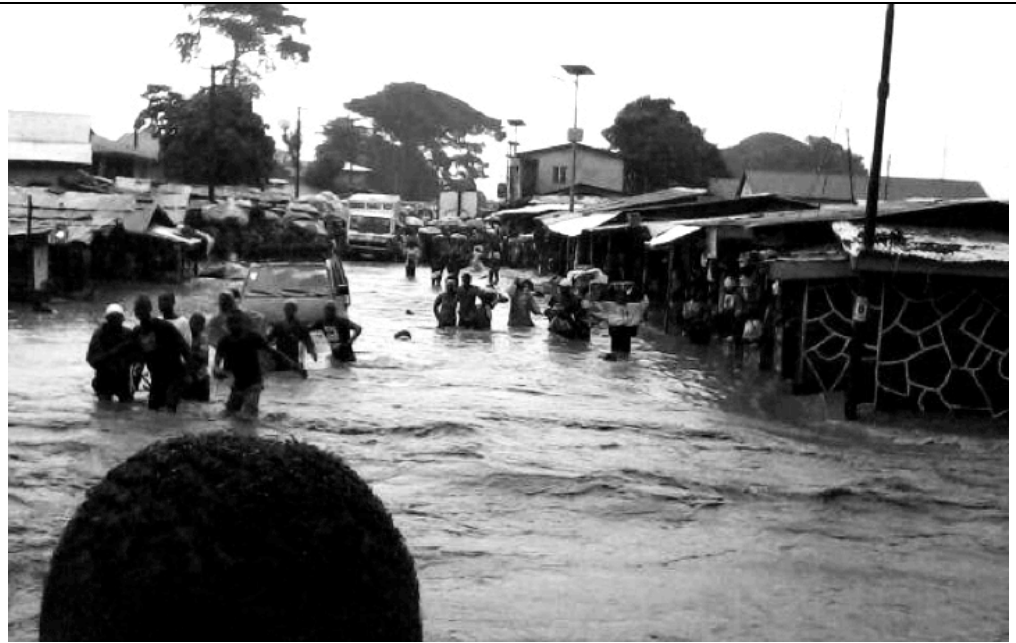

Fig. 3 In Sierra Leone, June to August is called "the hungry season," when heavy rains make it hard to harvest and obtain food.

Resource exploitation and extreme weather displaces farmers that practice mostly subsistence farming in rural communities. They have to venture deeper into forests in search of land and new livelihoods, bringing them in closer contact with infected animals (WHO 2015), while human activities cause bats and other animals to venture closer to human habitats.

Women accounted for roughly 60 to 75 percent of deaths in the 2014 Ebola epidemic (Wolfe 2014). Ebola's gendered impacts - including greater fatality rates for pregnant women, higher risks for caregivers who are often women, and dangers from sexual violence due to Ebola-related economic collapse (Thomas 2014) -- have implications for social resilience, survival of caregivers and mothers, economic decline and subsequent recovery in disease-affected areas, and the strength of public health systems (Perkins 2014).

When economic and ecological pressures, exacerbated by climate change, bring people and animals into closer contact while uprooting communities, depleting health care systems, undermining social resilience, and degrading infrastructure, this becomes a "perfect storm" for the emergence and spread of infectious disease. 


\section{Stigmatization and the Local and Global Response to Ebola}

Disease ecology reminds us that the transmission dynamics of infectious disease spread involves a complex interplay between natural ecosystems, human economic activity and cultural belief systems (Mayer 2000). An oft-neglected consideration of the disease ecology is the role that stigmatization may play in disease transmission dynamics. Stigma is a common aspect of all cultural systems and quite often used in the service of social control (Goffman 1963). As such, despite the reality of the lethality of Ebola, the challenges that stigmatization poses for the effectiveness of outbreak response should not be trivialized. Patients may conceal the fact that they are infected, for various reasons related to stigmatization. For instance, one Liberian physician observed that "Some patients don't tell the truth. They come to you with a different story, like 'abdominal pain'. It's because of the stigma of Ebola. They think they won't be treated and they'll be sent away" (York 2014c). Stigmatization in the Ebola outbreak situation is not limited to patients. Health care workers, for example, were evicted from their homes by landlords out of fear (York 2014b). Furthermore, mobs in rural villages attacked journalists and health care workers (including those engaged in educational efforts but especially those responsible for removing the deceased). Similar to the situation with HIV/AIDS (Lewis 2006), orphans whose parents had succumbed to Ebola also became stigmatized during the earlier stages of the outbreaks. Given that UNICEF found that as of 6 February 2015, there existed 16,000 orphans in the Ebola-affected West African countries (UN NewsCentre 2015), the potential for a tragic problem has loomed. However, a UNICEF official remarked on a positive note that:

There were fears that stigma around Ebola would isolate the orphaned children, which would mean there would be thousands of abandoned children, but that has, luckily, not materialized. (UN NewsCentre 2015:n.p.).

UNICEF programs provided cash support, material assistance, psycho-social support, and implemented programs to refer families for food assistance. This collectively helped to mitigate the effects of stigmatization and led to eighty per cent of the orphaned children being reunified with their extended families (ibid.).

Combatting stigma in populations where half the population is illiterate poses challenging problems. Programs that have successfully addressed such challenges may however be found. In Monrovia, billboards and posters visible on every major street helped to raise awareness, while thousands of "social mobilizers", consisting of health workers, teachers, religious leaders and youth activists, were recruited in Ebolaaffected areas to spread the message about the disease (York 2014b). UNICEF produced videos and catchy songs with the same intent (ibid.).

Public health responders from outside West Africa were themselves hampered by stigmatization. This is an especially important issue in light of the observation by the WHO Director-General that the Ebola outbreak response urgently required outside assistance (Weintraub 2014). Western hospitals were reluctant to allow medical staff to go to West Africa, or take in Ebola-infected patients, due to worries of being labelled as the "Ebola hospital" in their community, or because of concerns that taking such actions would cause anxiety amongst in-house hospital staff (York 2014a). At another level, stigmatization may be understood as coming from the conflation of race with disease. This association may be bolstered by the term "Ebola" itself. According to one 
linguist, "Ebola" connotes to American listeners the very idea of Africa because of its sound similarities to 'ebonics' or 'ebony' in the American vernacular (Troutman 2014).

These types of stigmatization have deep structural origins that can be traced to the legacies of imperialism and colonialism in which "tropicality" is associated with disease (Bankoff 2001). In this type of colonialist discourse, other parts of the world are depicted as dangerous, particularly those with "warm climates" from where "new and emerging diseases" are seen to emanate in the 21 st century (ibid). The effects of such neocolonial influences are seen, for example, in the way in which medical research in the Global North has benefited from blood, parasites, and viruses collected from the people of the Global South. The patented vaccines developed from such materials benefit those in the Global North (and especially the private pharmaceutical countries). As noted by Fearnley (2015), such biomedical gains did little to help build public health capacity and infrastructure within West Africa. Dealing with such enduring forms of stigmatization is vexing because of the structural dimensions involved in the geopolitics of dependency and Global North-South relations. One way forward, however, may be seen in the recent efforts of the African Union to establish an Ebola Solidarity Fund and an African centre for disease control by mid-2015 (Anders 2015). This initiative may have the potential to serve as an impetus to organize and institutionalize efforts against the types of stigmatization that ensue from structural dependency and power differentials embedded in neocolonialism.

While Ebola may be lethal for those contracting the disease, many, especially the medical practitioners involved in fighting Ebola (see Gbakima et al. 2014), as well as a number of mainstream journalists, have pointed to the media sensationalism surrounding the disease. As such it has been noted that there is a "tendency (in) the international media to attract viewers (which) has led some careless journalists to focus almost exclusively on the fear-invoking mode of death from the disease" such as the garish images of victims "coughing up blood" (Wallace 2014). Such foci are often fed by stereotypes about Africa, which are also linked to the oft-depicted image of Africa as a site of primitivism and catastrophe, the sources of which lie in colonial discourses of backwardness, exoticism and savagery. Thus, while it may be that having a fear of Ebola is a somewhat understandable response and not in itself a colonial attitude, the colonial legacy nevertheless exerts a tacit and often unrecognized influence on the fear. Specifically, it may "fan the flames of fear" or to put it in more technical terms, the colonial legacy may contribute to the phenomenon known as the "social amplification of risk", whereby peoples' perceptions of risk are unreasonably intensified (Kasperson et al. 1988).

\section{Community Engagement and the Ebola Response}

One criticism of the international Ebola response has been the failure of some international agencies to partner effectively with local government agencies, NGOs, and community organizations to respond appropriately and effectively to the epidemic, and to build capacity for the future (Gundan 2014; Kaba Jones and Norman 2014). The need to engage communities in successful health initiatives is well-established (Israel et al. 1998) and yet this seems to have been lost in the urgency of the international response. International initiatives responding to the Ebola epidemic focused on immediate treatment responses, the development and delivery of vaccines, security and containment, and large initiatives like building hospitals. For example, Canada's contribution to the Ebola campaign was the provision of protective gear, setting up mobile labs, and the delivery of an experimental vaccine (Public Health Agency of 
Canada 2014). At best, these responses have been slow, expensive, difficult to coordinate, and unsustainable (Gundan 2014). At their worst, the responses met resistance by local populations, and were slow to adapt to the local contexts thus rendering such responses ineffective and inefficient, and in the end, leaving the communities vulnerable to the next health crises.

The importance of acknowledging and respecting concerns and practices of local communities and their socio-political context has been identified as a major issue in implementing health policies and practices (Nichter 2008). In reviewing the trajectory of the response to the Ebola outbreak, Petherick (2015) noted the general lack of trust between medical teams and local communities. This lack of trust contributed to community responses ranging from hiding Ebola cases from health workers, to attacking health workers and health facilities, driven by the belief that medical staff were spreading the infection, rather than trying to contain it. Mitman (2014) argues that the colonial history between Africa and Europe is one underlying source of this mistrust, a history that begins with slave traders and missionaries and continues with the current European exploitation of resources and labour and Western military involvement in a range of conflicts. In the early to mid 1900s, American medical researchers followed this path of exploitation, extracting blood, tissue and, ultimately, knowledge, on expeditions to Africa, with some amount of coercion and without benefit or explanation to local populations (Karamouzian and Hategekimana 2015). This history of violence, invasion and exploitation has not been forgotten and could only have been reinforced by the presence of Western military personnel supporting biohazard-suited health workers (Bayntun, Houlihan and Edmunds 2014).

Community based health initiatives are rapid and culturally appropriate responses from agencies trusted by the communities, and as such are more likely to be successful (Teutsch and Fielding 2013). Effective and innovative grassroots community led responses began immediately in Ebola-affected areas across West Africa and have been successful (Kaba Jones and Norman 2014). Moreover, strengthening these local community organizations can also be part of a strategy to build primary health care in general (Anders 2014). However, obtaining international support for grassroots initiatives is challenging. Most international funding is directed to EU or US organizations, which may have local initiatives and a history of working successfully in the area, but little funding is generally directed to local grassroots organizations or to the development of sustainable health infrastructure (Gundan 2014).

The Ebola epidemic rose rapidly in countries experiencing severe poverty, with a recent history of political unrest and conflict, and with very poor health care systems and infrastructure. Prevention of future epidemics requires development of strong social, political and health infrastructure (Kaba Jones and Norman 2014). The challenge is that international responses often do little to produce sustainable development. In an interview with journalist Flavie Halais, development expert Ian Smillie noted that Canada's interventions in Sierra Leone would have no lasting impact on the health care system (Halais 2014), and thus make no contribution towards the prevention of future epidemics.

Representatives of the U.K. Department for International Development (DfID) now claim that they should have focused on prevention and social mobilization earlier, and funneled more funding to local grassroots organizations to do so effectively (Jóźwiak 2015). In the same article, however, the author noted that DfID's funding policies made it difficult to fund local agencies, and that they report no plans to shift funding 
The Social and Political Dimensions of the Ebola Response...

policies, reflecting the disconnect between evidence based practices in population health, and the politics of international aid funding.

\section{Conclusion: Climate Change, Social Resilience, and Emerging Dis- eases}

Ebola is a well-studied disease, not an unknown one like SARS was when it first appeared in 2003, with a fatality rate of 18 percent. Ebola's genomes have been sequenced and patented, and supportive health care can reduce its fatality rate to about 20 percent, according to health researcher Laurie Garrett (CBC 2015). But as former WHO staffer Akong Charles Ndika notes, the desperate state of most African healthcare systems enables the threat posed by Ebola outbreaks to be maintained, and these inequities "will continue in [the] future to manufacture new and re-emerging epidemics like Ebola ... with frightening impact on a global scale" (Ndika 2014:n.p.).

Moral panic is not helpful. Health-care workers need the training and equipment to protect themselves, and basic health education for the general public is crucial to counter stigma, fear, ignorance, and superstition. Participatory education and logistics are the main challenges, not just to build hospitals and public health interventions, but also to support food security, infrastructure and governance systems, especially at local levels across the Global South. This is a huge and pressing endeavour which only the WHO can coordinate, working closely with local institutions. So the WHO must be supported -- not just in words but with significant financial and material resources - in order to meet the immediate challenges of new disease outbreaks and also to build the longer-term capacity of local public health agencies so that local units can function effectively and sustainably, since future outbreaks are inevitable in today's globalized world. This applies not only to the need to increase the supply of material resources needed for the emergency response, but also the training of local staff so that they can thwart the threat themselves. Broad public participation in governance of the entire health care system is also necessary, both locally and globally, so that education and democracy go hand in hand with the development of strong health care systems. Urban public health systems should become a prime focus of WHO and international support.

Analysis of the social and economic roots of the Ebola epidemic demonstrates that the 2014 crisis was grounded in global income inequality and the same impoverishment that had opened up countries for land grabbing, rapacious foreign direct investment and agro-forestry, the displacement of more and more people, the destruction of natural habitats and the erosion of the capacity for social resilience. These conditions will continue to produce outbreaks of emergent diseases in times of climate change, and unless they are addressed, these outbreaks will continue to facilitate ongoing global health threats.

\section{References}

Action Aid (2006) Unjust waters: Climate change, flooding and the protection of poor urban communities: experiences from six African cities. London http://www.actionaid.org/publications/unjust-waters-climate-change-flooding-andprotection-poor-urban-communities. Accessed 14 June 2015

Afri-Dev.Info (2014) African factsheet on Ebola challenges, health workforce and human resources for health shortages. Africa Health, Human and Social Development Infor- 
mation Service, Lagos. http://www.afri-

dev.info/sites/default/files/2014\%20Africa\%20Factsheet\%20on\%20Ebola\%20Challan ges, $\% 20 \mathrm{Health} \% 20 \mathrm{Workforce} \% 20 \% 26 \% 20 \mathrm{Human} \% 20$ Resources $\% 20$ for $\% 20 \mathrm{Health} \%$ 20Shortages-fin.pdf . Accessed 16 February 2015

Ali SH, Keil R (2008) Networked disease. Emerging diseases in the global city. Blackwell, Oxford

Anders M (2014) Ebola responders tap past survivors. Youth in community-based strategy. https://www.devex.com/news/ebola-responders-tap-past-survivors-youth-incommunity-based-strategy-84598. Accessed 18 February 2015

Anders M (2015) Post-Ebola, AU plans pan-African CDC. https://www.devex.com/news/postebola-au-plans-pan-african-cdc-85384. Accessed 9 February 2015

Baize S, Pannetier D, Oestereich L, Rieger T, Koivogui L, Magassouba,N, Magassouba N, Soropogui B, Sow MS, Keita S, De Clerck H, Tiffany A, Dominguez G, Loua M, Traoré A, Kolié M, Malano ER, Heleze E, Bocquin A, Mély S, Raoul H, Caro V, Cadar D, Gabriel M, Pahlmann M, Tappe D, Schmidt-Chanasit J, Impouma B, Diallo AK, Formenty P, Van Herp M, et al. (2014) Emergence of Zaire Ebola virus disease in Guinea. New England Journal of Medicine 371(15):1418-1425

Bankoff G (2001) Rendering the world unsafe: 'Vulnerability' as Western discourse. Disasters 25(1):19-35

Bayntun C, Houlihan C, Edmunds J (2014) Ebola crisis: Beliefs and behaviours warrant urgent attention. Lancet 384:1424

Bloch R (2015) Africa's new suburbs. In: Hamel P, Keil R (eds) Suburban Governance: A Global View. University of Toronto Press, Toronto, pp 253-277

Bloch R, Papachristodoulou N, Brown D (2013) Suburbs at Risk. In: Keil R, Suburban constellations: Governance, land and infrastructure in the 21st Century, Jovis, Berlin, pp 95-101

Brenner N (2014) Implosions / Explosions. Jovis, Berlin

BTI (2012) Sierra Leone country report. Bertelsmann Stiftung's Transformation Index (BTI) http://www.btiproject.org/fileadmin/Inhalte/reports/2012/pdf/BTI-201-SierraLeone.pdf. Accessed 12 October 2012

CBC (2015). CSI Ebola: Tracking the outbreak's origins. Quirks and Quarks, Canadian Broadcasting Corporation. http://www.cbc.ca/quirks/listen/. Accessed 20 February 2015

Chippaux J (2004) Pratique des essais cliniques en Afrique. Paris, IRD Editions

Cockerham GB, Cockerham WC (2010) Health and globalization. Polity, Cambridge

Cohen JC, Illingworth P, Schuklenk U (2006) The Power of Pills. Pluto Press, London

Diallo B, Dilorenzo S (2014) Ebola making a comeback in places it was contained. The Toronto Star, September 8 http://www.thestar.com/news/world/2014/09/08/ebola making a comeback in places it was contained.html. Accessed 12 June 2015

Dumont JC, Zurn P (2007) Immigrant health workers in OECD countries in the broader context of highly skilled migration. International migration outlook, 162-228 http://www.oecd.org/migration/mig/41515701.pdf Accessed 14 June 2015

Fearnley L (2015) The disease that emerged. Limn Issue Number 5, Ebola's Ecologies (January) http://limn.it/the-disease-that-emerged/. Accessed 9 February 2015

Fofana U (2014) Sierra Leone Ebola patient, recovered from family, dies in ambulance. Reuters, July 27. http://uk.reuters.com/article/2014/07/27/uk-health-ebola-africaidUKKBNOFVONR20140727. Accessed 28 May 2015

Frumkin H, Hess J, Luber G, Malilay J, McGeehin M (2008) Climate change: The public health response. American Journal of Public Health, 98(3), 435-445 
The Social and Political Dimensions of the Ebola Response...

Gbakima AA, Gonzalez J, Wolfe ND (2014) The truth about Ebola: The real way to control Ebola is to stop the fear and misunderstanding. Time, 1 August, n.p. http://time.com/3069876/ebola-outbreak-truth/ Accessed 14 June 2015

Gundan F (2014) Liberia: How Africa and Africans are responding to the Ebola crisis. Forbes. http://www.forbes.com/sites/faraigundan/2014/10/28/liberia-how-africa-and-africansare-responding-to-the-ebola-crisis/. Accessed 18 Feb 2015

Goffman E (1963) Stigma: Notes on the Management of Spoiled Identity. Prentice Hall, Englewood Cliffs NJ

Halais F (2014) Money (not) well spent? Concerns raised over Canada's response to Ebola. Devex, 20 October. https://www.devex.com/news/money-not-well-spent-concernsraised-over-canada-s-response-to-ebola-84590. Accessed 18 Feb 2015

Harman, S (2009) The World Bank and health. In: Kay A, Williams O (eds) Global health governance: crisis, institutions and political economy, Palgrave-Macmillan, New York, pp 227-242

Healy D (2012). Pharmageddon, Berkeley, University of California Press

Israel BA, Schulz AJ, Parker EA, Becker AB (1998) Review of community-based research: assessing partnership approaches to improve public health. Annual Review of Public Health (19)173-202

Jóźwiak G (2015) DfID has learned 'a lot' in Ebola response. Devex, 13 February 2015. https://www.devex.com/news/dfid-has-learned-a-lot-in-ebola-response-85427. Accessed 18 Feb 2015

Kaba Jones S, Norman D (2014) Fighting Ebola from the grassroots. Agenda; World Economic Forum. https://agenda.weforum.org/2014/10/ebola-virus-health-lessons/. .Accessed 18 Feb 2015

Karamouzian M, Hategekimana C (2015) Ebola treatment and prevention are not the only battles: Understanding Ebola-related fear and stigma. Int J Health Policy Manag (4)55-56

Kasperson RE, Renn O, Slovic P, Brown H, Emel J, Goble R, Kasperson J, Ratick S (1988) The Social amplification of risk: A conceptual framework. Risk Analysis 8(2):177

Kay A, Williams, OD (2009) Introduction: The international political economy of global health governance. In: Kay A and Williams OD (eds.), Global health governance crisis, institutions and political economy, Palgrave-Macmillan, New York, pp 1-25

Keil R (2011) Transnational urban political ecology: health, environment and infrastructure in the unbounded city, In: Bridge $\mathrm{G}$ and Watson $\mathrm{S}$ (eds.) The New Companion to the City. 2nd ed. Wiley-Blackwell, Oxford

Keil, R (ed.) (2013) Suburban Constellations: Governance, Land and Infrastructure in the 21st Century Jovis, Berlin

Keil, R (2014) Diseased. In: Adey P, Bissell D, Hannam K, Merriman P, Sheller M (eds.) The Handbook of Mobilities, Routledge, London, pp 388-97

Klenk, NL, Meehan K (2015) Climate change and transdisciplinary science: Problematizing the integration imperative. Environmental Science and Policy, in press

Leahy S (2011) In corrupt global food system, farmland is the new gold. Inter Press Service: www.ipsnews.net/2011/01/in-corrupt-global-food-system-farmland-is-the-new-gold/. Accessed 15 Feb 2015

Lee K (2009) The World Health Organization (WHO). Routledge, Oxford.

Lewis S (2006) Race against time: Searching for hope in AIDS-ravaged Africa. House of Anansi Press, Toronto

Mabin A (2013) Suburbanisms in Africa? In: Keil R, Suburban Constellations: Governance, Land And Infrastructure In The 21st Century. Jovis, Berlin, pp 154-160

Mayer JD (2000) Geography, ecology and emerging infectious diseases. Social Science and Medicine 90:937-52 
Mitman G (2014) Ebola in a Stew of Fear. New England Journal of Medicine, 371(19):17631765

Moran-Ellis J, Alexander VD, Cronin A, Dickinson M, Fielding J, Sleney J, Thomas H (2006) Triangulation and integration: Processes, claims and implications. Qualitative Research 6(1):45-59.

MSF (2014) Ebola crisis update - Sept $25^{\text {th }}$. Médecins Sans Frontières International. http://www.msf.org/article/ebola-crisis-update-sept-25th Accessed 14 June 2015

Ndika AC (2014) Ebola: Recovery of Americans sharpens divisions in global health. Pambazuka News, 693, 2014-09-11 http://www.pambazuka.net/en/category.php/features/92866 Accessed 20 February 2015

Nichter M (2008) Global health: Why cultural perceptions, social representations and biopolitics matter. University of Arizona Press, Tucson

Observer Editorial (2014) The Observer view on the Ebola outbreak. http://www.theguardian.com/commentisfree/2014/oct/05/observer-view-on-ebolacrisis-editorial Accessed February 19, 2015

Oladele DA, Oyedeji KS, Niemogha MT, Nwaokorie F, Bamidele M, Musa AZ, et al. (2012) An assessment of the emergency response among health workers involved in the 2010 cholera outbreak in northern Nigeria. Journal of infection and public health 5(5):346353

Olaniyan T (2004) Africa: Varied colonial legacies. In: Schwarz H, Ray S, A companion to postcolonial studies, Wiley-Blackwell, Oxford, pp 269-281

Oxfam 2008. Another inconvenient truth: how biofuel policies are deepening poverty and accelerating climate change. Briefing Paper No. 114. Oxfam Great Britain, Oxford

PHM (2014) Ebola epidemic exposes the pathology of the global economic and political system. People's Health Movement.

http://www.phmovement.org/sites/www.phmovement.org/files/phm ebola 2309201 4final 0.pdf Accessed February 14, 2015

Perkins, PE (2014) Climate justice and gender justice: Building women's political agency in times of climate change. Paper presented at the International Association for Feminist Economics (IAFFE) conference, Accra, Ghana, June 27-29. http://editorialexpress.com/conference/IAFFE23AC/program/IAFFE23AC.html\#5. Accessed 15 June 2015

Petherick A (2015) Ebola in West Africa: learning the lessons. The Lancet 385: 591-592

Pinzon JE, Wilson JM, Tucker CJ, Arthur R, Jahrling PB, and Formenty P (2004) Trigger events: Enviroclimatic coupling of Ebola Hemorrhagic Fever outbreaks. The American Journal of Tropical Medicine and Hygiene, 71(5):664-674

Poteete AR, Janssen MA, Ostrom E (2010) Working together: Collective action, the commons, and multiple methods in practice. Princeton University Press, Princeton and Oxford

Price-Smith AT (2009) Contagion and chaos: Disease, ecology and national security in the era of globalization. MIT Press, Cambridge

Public Health Agency of Canada (2014) Speaking notes for the Honorable Rona Ambrose, Minister of Health: the Government's response to the Ebola outbreak. Government of Canada. http://news.gc.ca/web/article-en.do?nid=900999. Accessed 18 February 2015

Rashid I (2011) Epidemics and Resistance in Colonial Sierra Leone during the First World War. Canadian Journal of African Studies/La Revue canadienne des études africaines, 45(3): 415-439

Roe E (1998) Taking complexity seriously: Policy analysis, triangulation and sustainable development. Kluwer Academic Publishers, Boston 
The Social and Political Dimensions of the Ebola Response...

Saéz, AM, Weiss S, Nowak K, Lapeyre V, Zimmermann F., Düx, A, et al. (2015) Investigating the zoonotic origin of the West African Ebola epidemic. EMBO molecular medicine, $7(1): 17-23$

Salaam-Blyther T (2014) The 2014 Ebola outbreak: International and U.S. responses. Congressional Research Service, 26 August http://fpc.state.gov/documents/organization/231281.pdf Accessed 14 June 2015

Seto KC, Güneralp B, Hutyra, LR (2012) Global forecasts of urban expansion to 2030 and direct impacts on biodiversity and carbon pools. Proceedings of the National Academy of Sciences, 109(40), 16083-16088

Shields R (2012) Feral suburbs: Cultural topologies of social reproduction, Fort McMurray, Canada. International Journal of Cultural Studies, 1367877911433743. 15,3:205-15

Stanford J (2014) Ebola vaccine story shows folly of free-market drugs. http://www.theglobeandmail.com/globe-debate/ebola-vaccine-story-shows-folly-offree-market-drugs/article21422767/. Accessed 28 May 2015

Teutsch SM, Fielding JE (2013) Rediscovering the core of public health. Annual review of public health (34):287-299

Thomas K (2014) Ebola's gender bias. World Policy Blog, December 18, 2014. http://www.worldpolicy.org/blog/2014/12/18/ebolas-gender-bias. Accessed 20 February 2015

Trenchard T (2014) Sierra Leone capital now in grip of Ebola. Aljazeera, 6 August http://www.aljazeera.com/news/africa/2014/08/rumours-complicate-sierra-leone-ebolabattle-20148373428495608.html Accessed 14 June 2015

Troutman E (2014) Race and disease: Should we change the name of Ebola? Aid.Works, 7 November http://aid.works/2014/11/race-and-disease-should-we-change-the-name-ofebola/. Accessed 9 February 2015

United Nations News Centre (2015) West African communities receiving Ebola's orphans with open arms, agency reports.

http://www.un.org/apps/news/story.asp?NewsID=50018\#.VWTOXmZEloC Accessed 9 February 2015

UNDP (2011) Sustainability and equity: A better future for all. United Nations Development Program Human Development Report.

http://hdr.undp.org/sites/default/files/reports/271/hdr_2011_en_complete.pdf. Accessed 15 October 2013

Wald P (2008) Contagious: cultures, carriers, and the outbreak narrative. Duke University Press, Durham

Wallace L (2014) Ebola's exaggerated fear being fed by stigma and stereotypes. Globe and Mail, 12 August. http://www.theglobeandmail.com/globe-debate/ebolas-exaggerated-fearbeing-fed-by-stigma-and-stereotypes/article20000080/. Accessed 14 June 2015

Weintraub K (2014) As Ebola's spread continues, warnings of an inadequate global response. National Geographic, 4 September http://news.nationalgeographic.com/news/2014/09/140903-ebola-global-responsewest-africa-world-health-medicine/. Accessed 14 June 2015

WHO (2009) Cities and public health crisis. World Health Organization. http://www.who.int/ihr/lyon/FRWHO HSE IHR LYON 2009.5.pdf. Accessed 14 June 2015

WHO (2012) Cholera in Sierra Leone: the case study of an outbreak: World Health Organization. www.who.int/features/2012/cholera_sierra_leone/en. Accessed 09 October 2013

WHO (2014a) Atlas of African health statistics 2014: Health situation analysis of African region. World Health Organization. https://www.aho.afro.who.int/en/atlas/atlas-africanhealth-statistics-2014-health-situation-analysis-african-region. Accessed 14 June 2015 
WHO (2014b) Global Alert and Response (GAR). Ebola Virus Disease outbreak response plan in West Africa, http://www.who.int/csr/disease/ebola/evd-outbreak-response-planwest-africa-2014.pdf?ua=1. Accessed 13 February 2015

WHO (2014c) Nigeria is now free of Ebola virus transmission. World Health Organization Updates, 20 October. http://www.who.int/mediacentre/news/ebola/20-october-2014/en/. Accessed 15 February 2015

WHO (2015) One year into the Ebola epidemic: A deadly, tenacious and unforgiving virus. World Health Organization Updates, January. http://www.who.int/csr/disease/ebola/one-year-report/introduction/en/. Accessed 15 February 2015

Wolfe L (2014) Why are so many women dying from Ebola? Foreign Policy. http://foreignpolicy.com/2014/08/20/why-are-so-many-women-dying-from-ebola/. Accessed 20 February 2015

York G (2014a) Only a few aid agencies willing to help fight Ebola in Africa, The Globe and Mail, 3 October, p A4. http://www.theglobeandmail.com/news/world/aid-agenciesfail-to-mobilize-ebola-resources/article20930983/. Accessed 14 June 2015

York,G (2014b) Fear and education play crucial role in Ebola crisis. The Globe and Mail, 9 October,p A1. http://www.theglobeandmail.com/life/health-and-fitness/health/fear-andeducation-play-crucial-role-in-ebola-crisis/article20999262/. Accessed 14 June 2015

York G (2014c) U.S. troops arrive in West Africa to help fight Ebola outbreak. The Globe and Mail, 28 September, p. A9. http://www.theglobeandmail.com/news/world/us-troopsarrive-in-west-africa-to-help-fight-ebola-outbreak/article20822003/. Accessed 14 June 2015

\section{Author Biographies}

Harris Ali (Ph.D. Sociology, McMaster University) is a Professor in the Faculty of Environmental Studies at York University, Toronto. His research focuses on the analyses of 'disaster incubation': how normally unnoticed social and ecological processes converge to create a disaster, including disease outbreaks. He is currently studying the social and political implications of oil sands extraction, with a special focus on the state surveillance and monitoring of environmental activists in Canada. He is a co-editor (with Roger Keil) of the volume Networked Disease: Emerging Infections in the Global City.

Barlu Dumbuya is a graduate student in the Disaster \& Emergency Management program with a concentration in environmental issues, technology and disaster management at York University. She is interested in social vulnerability, community resilience and capacity building in developing countries.

Michaela Hynie (Ph.D McGill) is a social and cultural psychologist in the Department of Psychology, York University and Associate Director of the York Institute for Health Research (YIHR). She conducts collaborative research with students, communities and organizations, both locally and internationally, on the relationship between different kinds of social connections (interpersonal relationships, social networks) and resilience in situations of social conflict and displacement, and interventions that can strengthen these relationships in different cultural, political and physical environments. This includes work on culture, migration and health inequities; climate change adaptation; and social integration of refugees. 
Pablo Idahosa (Ph.D. Political Economy, University of Toronto) is a professor in the Department of Social Science at York University, where he directs the African Studies program, and teaches development studies. He has written on development ethics, the politics of ethnicity, and national development. He is author of The Populist Dimension of African Political Thought, coeditor of The Somali Diaspora, and co-editor of Development's Displacements. Among his ongoing research interests are the relationships between development and cultural production in Africa, and the politics of disease in Africa. He is formerly executive of the International Development Ethics Association. He is completing a book on Social Welfare in Africa.

Roger Keil (Dr.Phil Political Science, Goethe University, Frankfurt) is York Research Chair in Global Sub/Urban Studies in the Faculty of Environmental Studies at York University in Toronto. A former director of York University's City Institute, he researches global suburbanization, urban political ecology, cities and infectious disease, and regional governance and is Principal Investigator of a Major Collaborative Research Initiative on "Global Suburbanisms: Governance, Land and Infrastructure in the 21st Century" (2010-2017). He is the editor of Suburban Constellations (Jovis 2013) and co-editor (with Pierre Hamel) of Suburban Governance: A Global View (UTP 2015).

Patricia E. Perkins (Ph.D. Economics, University of Toronto) is a Professor in the Faculty of Environmental Studies, York University, Toronto, where she teaches and advises students in the areas of ecological economics, community economic development, and critical interdisciplinary research design. Her research focuses on feminist ecological economics, climate justice, and participatory governance. She has directed international research projects on community-based environmental and watershed education in Brazil and Canada and on climate justice and equity in watershed management with partners in Mozambique, South Africa and Kenya, and is the editor of Water and Climate Change in Africa: Challenges and Community Initiatives in Durban, Maputo and Nairobi. 